\title{
IMPLIKASI HUKUM ASAS PRADUGA BERSALAH YANG DIGUNAKAN WARTAWAN DALAM PEMBERITAAN PERKARA PIDANA
}

\author{
Hanugrah Titi Habsari S. \\ Lembaga Bantuan Hukum Rumah Keadilan \\ Jalan Kembang Kertas Gg. IV Kavling 09 Malang - 65146 \\ Email: hanugrahtitihabsari@gmail.com
}

\begin{abstract}
In the Indonesian Journalist's code of ethic, one of the principle regulated is respecting presumption of innocence principle. But when journalist report criminal case, they do not fully take respect for such principle, for example in Jessica Kumala Wongso case. Furthermore, there isn't any specific regulation when breaking the principle. The problem is, many journalist are criminalized by article 310 (2) of the Indonesian Criminal Code. The purpose of this research is finding the real principle ] used by journalist when reporting criminal case and the legal implication of such violation. The method used in this research is library research with grammatical and systematical interpretation technique. This result shows that in in theoretical and practical, journalist applying different principal when reporting criminal case. The principal that used by journalist is presumption of guilt principal. As a result of applying presumption of guilt principal, journalist are considered to insult and make article 310 (2) KUHP as the only way out for journalist that considered to do insult. As a manifestation of restorative justice, a concept of penal mediation for journalist that has considered to do insult has been submitted.
\end{abstract}

Key words: presumption of innocence, presumption of guilt, journalist

\begin{abstract}
Abstrak
Kode Etik Wartawan Indonesia salah satunya mengatur bahwa wartawan diharuskan untuk menghormati asas praduga tak bersalah. Akan tetapi dalam praktik pemberitaan perkara pidana, wartawan tidak sepenuhnya menghormati asas praduga tak bersalah. Hal ini dapat dicontohkan pada pemberitaan kasus Jessica Kumala Wongso. Selain itu, sampai saat ini tidak ada peraturan yang mengatur secara khusus untuk wartawan selain pada kode etik, jika muncul sebuah pelanggaran penghormatan terhadap asas praduga tak bersalah. Permasalahan muncul ketika wartawan banyak dikriminalisasi dengan Pasal 310 (2) KUHP. Tujuan dari tulisan ini untuk menemukan asas yang seharusnya digunakan wartawan sebagai landasan untuk mempublikasikan perkara pidana dan implikasi hukum apabila publikasi perkara pidana oleh wartawan bertentangan dengan asas praduga tak bersalah. Tulisan ini didasarkan pada penelitian hukum normatif dengan teknik pengumpulan bahan hukum melalui studi kepustakaan menggunakan teknik interpretasi gramatikal dan sistematis. Dari penelitian tersebut diketahui bahwa secara teori dan praktik, wartawan menerapkan hal yang berbeda dalam melakukan pemberitaan perkara pidana. Asas yang digunakan wartawan dalam melakukan pemberitaan perkara pidana yaitu asas praduga bersalah. Sebagai akibat penggunaan asas praduga bersalah, wartawan seringkali dianggap melakukan penghinaan/pencemaran dan menjadikan Pasal 310 ayat (2) KUHP sebagai jalan terakhir bagi wartawan yang melakukan penghinaan/pencemaran.
\end{abstract}


Sebagai perwujudan keadilan restoratif, diajukan sebuah konsep mediasi penal bagi wartawan yang melakukan penghinaan/pencemaran.

Kata kunci: praduga tak bersalah, praduga bersalah, wartawan

\section{Latar Belakang}

Komunikasi merupakan salah satu kebutuhan yang tidak bisa terlepas dari kehidupan manusia saat ini. Bentuk komunikasi ada berbagai macam, sebagai contohnya yaitu menyatakan diri, berbicara, menerima dan menyampaikan informasi maupun pesan, serta berbagai kegiatan lainnya. ${ }^{1}$ Sebagai sarana untuk menyampaikan bentuk komunikasinya, manusia memerlukan sebuah wadah atau lembaga yang dapat mengakomodasi segala macam bentuk komunikasi yang bermacam-macam. Manusia juga memerlukan komunikasi untuk mengetahui perkembangan lingkungan sekitar serta informasi-informasi akurat. Informasi yang akurat memerlukan proses pencarian yang panjang, mulai dari pencarian berita, pemberitahuan oleh informan, wawancara pada narasumber, hingga proses penulisan berita, editing, hingga beredarnya berita yang dapat dinikmati masyarakat. Maka dari itu diperlukan sebuah wadah untuk mengelola kegiatan pencarian berita hingga peredaran berita yang kemudian dibentuklah lembaga
Pers untuk menjawab kebutuhan masyarakat akan informasi tersebut.

Pers memiliki pengertian yang luas. Pengertian pers secara harfiah mengacu pada komunikasi yang dilakukan melalui perantaraan hasil cetakan. Tapi saat ini, pers telah mengalami pengembangan secara pengertiannya. Pengertian pers memiliki dua artian, arti sempit dan arti luas. ${ }^{2}$ Pengertian pers secara luas dan secara sempit ini menyangkut tentang kegiatan komunikasi. ${ }^{3}$ Kegiatan komunikasi yang dimaksud yaitu media yang digunakan. Pengertian secara luas menggunakan media selain media cetak. Dalam era globalisasi seperti saat ini, penggunaan internet sudah menjadi kebiasaan sehari-hari. Pergeseran kebiasaan secara perlahan dari penggunaan media cetak menjadi media elektronik seperti radio, televisi dan internet. Sedangkan untuk pengertian pers secara sempit yaitu penyiaran-penyiaran oikiran, gagasan, ataupun berita-berita dengan jalan kata tertulis. ${ }^{4}$

Pada peraturan perundang-undangan, Indonesia memiliki peraturan terkait Pers

1 McLuhan dalam Edy Susanto, dkk, Hukum Pers di Indonesia, (Jakarta: Rineka Cipta, 2010), hlm. 20.

2 Ibid., hlm. 19.

3 Jacob Oetama, Perspektif Pers Indonesia, (Jakarta: LP3ES, 1987), hlm. 4.

4 Alex Sobur, Etika Pers (Profesionalisme Dengan Hati Nurani), (Bandung: Humaniora Utama Press, 2001), hlm. 146. 
yaitu Undang-undang Nomor 40 tahun 1999 tentang Pers (yang selanjutnya disebut UU Pers). Pada UU Pers disebutkan pengertian mengenai pers. Pengertian pers tercantum pada UU Pers Pasal 1 butir $1 .^{5}$

Berdasarkan pengertiannya, pers merupakan sarana sosialisasi per excellentiam, apapun yang dilakukan lewat pers kemudian berubah wujudnya menjadi sosial: komunikasi pribadi menjadi pergaulan sosial, kritik pribadi menjadi kritik sosial dan peringatan pribadi menjadi kontrol sosial. Dengan kata lain, apapun yang diumumkan melalui pers sebenarnya telah keluar dari ruang privat dan memasuki forum publicum. ${ }^{6}$

Berdasarkan Pasal 3 UU Pers, ditentukan bahwa fungsi dari Pers adalah sebagai fungsi media informasi, pendidikan, hiburan, kontrol sosial dan sebagai lembaga ekonomi. Sebagai lembaga ekonomi, perusahaan pers diselenggarakan berdasarkan prinsip ekonomi. Hal ini dilakukan guna menaikkan kualitas pers dan kemakmuran wartawan dan karyawan media, tanpa melupakan kewajiban sosialnya. $^{7}$

Selain fungsi tersebut diatas, pers memiliki fungsi sebagai pers yang bertanggung jawab. Fungsi tersebut yaitu fungsi informatif, fungsi kontrol, fungsi interpretatif dan direktif, fungsi menghibur, fungsi regeneratif, fungsi pengawalan hak-hak warga negara, fungsi ekonomi dan fungsi swadaya. ${ }^{8}$ Fungsi yang menjadi fokus dalam penulisan ini yaitu fungsi informatif. Fungsi informatif yaitu memberikan informasi atau berita kepada khalayak ramai dengan cara yang teratur. ${ }^{9}$ Pers menghimpun berita yang dianggap berguna dan penting bagi orang banyak dan kemudian menuliskannya dalam bentuk kata-kata.

Merangkai kata untuk menjadi sebuah artikel bukanlah hal yang mudah. Secara teoritis, dalam penulisan artikel, khususnya artikel hukum, wartawan diharuskan mengacu pada "Sepuluh Pedoman Penulisan tentang Hukum". Sepuluh Pedoman Penulisan tentang Hukum merupakan hasil Karya Latihan Wartawan (KLW) ke-12 yang diselenggarakan oleh Persatuan Wartawan Indonesia (PWI) yang bekerjasama dengan Lembaga Bantuan Hukum (LBH) Jakarta di Cibulan, Bogor, pada tanggal 24-30 Juli 1977. ${ }^{10}$ Pada "Sepuluh Pedoman Penulisan tentang Hukum" termuat bahwa wartawan diharuskan menghormati asas praduga tak bersalah dalam menulis dan menyajikan beritanya. Selain itu wartawan juga diharuskan untuk menjaga sikap terhadap

5 Pasal 1 Undang-undang Nomor 40 tahun 1999 tentang Pers: "Lembaga sosial dan wahana komunikasi massa yang melaksanakan kegiatan jurnalistik meliputi mencari, memperoleh, memiliki, menyimpan, mengolah, dan menyampaikan informasi baik dalam bentuk tulisan, suara, gambar, suara dan gambar, serta data dan grafik maupun dalam bentuk lainnya dengan menggunakan media cetak, media elektronik, dan segala jenis saluran yang tersedia."

6 Op.cit., hlm. X pengantar.

7 Lihat Penjelasan Pasal 3 ayat 2 UU Pers.

8 Hikmat Kusumaningrat dan Purnama Kusumaningrat, Jurnalistik, Teori dan Praktek, (Bandung: Rosda Karya, 2005), hlm. 27-29.

9 Edy Susanto, dkk, op.cit., hlm. 40.

10 Ibid., hlm. 315. 
jenis pidana dan tertuduh serta memperhatikan nada dan gaya dari tulisan yang harus tetap berada di posisi netral. Hal ini sangat penting agar tertuduh terhindar dari "trial by press".

Trial by press $^{l 1}$ atau trial by media terjadi ketika media massa baik cetak maupun elektronik membuat berita berupa suatu kasus yang berisi tuduhan serta penghakiman terhadap tersangka bahkan sebelumpengadilan mengeluarkan putusan terhadap kasus tersebut. Pengadilan oleh media merupakan interferensi pada proses pengadilan. Hal ini terjadi karena pemberitaan media dapat dengan mudah memengaruhi pola pikir dan pandangan seseorang terkait kasus dan setiap pihak yang turut serta. Sebagai akibat dari perbuatan tersebut, wartawan dinilai melanggar hak asasi orang yang dituduh melalui media massa atas asas praduga tak bersalah. ${ }^{12}$ Persepsi pembaca berita sangat beragam karena berasal dari berbagai kalangan yang tidak semua memahami istilahistilah hukum. Hal ini dapat diperparah lagi dengan tersisipnya opini media massa yang menyudutkan secara halus. Tuduhan yang tidak terbukti, dapat dikategorikan sebagai tindak pidana penghinaan/pencemaran oleh pers. Efek negatif trial by press tidak berhenti begitu saja. Tuduhan yang menghakimi tersangka sebelum pengadilan memutuskan, dapat berakibat buruk bagi tersangka dan keluarganya. Eksploitasi berita yang berlebihan hingga bersifat menyudutkan akan menimbulkan stigma di masyarakat karena tersangka dianggap telah tersentuh oleh proses peradilan yang sebenarnya belum tentu bersalah. ${ }^{13}$ Pemberitaan semakin tersebar dengan dalih sebagai transparansi hukum oleh negara sebagai salah satu bentuk kontrol oleh masyarakat. ${ }^{14}$

Adapula pengaturan dalam UU Pers yang mengatur tentang keutamaan pers dan wartawan menggunakan asas praduga tak bersalah dalam menyusun berita. Pengaturan mengenai hal ini terdapat dalam Pasal 5 ayat (1). ${ }^{15}$ Contoh kasus yang sempat menarik perhatian publik yaitu kasus pembunuhan Mirna Wayan Salihin oleh Jessica Kumala Wongso. Media saling beradu kecepatan menemukan fakta untuk konsumsi masyarakat. Keinginan media sangat besar hingga menyiarkan persidangan Jessica mulai dari pagi hari hingga pagi hari lagi secara langsung. Bahkan ada stasiun TV swasta yang sampai menghadirkan ahli guna memberikan komentar terkait apapun mengenai Jessica,

11 Trial by press dijelaskan dalam penjelasan Pasal 5 ayat (1) yaitu dalam hal menyiarkan informasi yang tidak menghakimi atau membuat kesimpulan kesalahan seseorang, terlebih lagi untuk kasus-kasus yang masih dalam proses peradilan.

12 Ibid., hlm. 122.

13 Oemar Seno Adji, Perkembangan Delik Pers di Indonesia, (Jakarta: Erlangga, 1990), hlm. 83.

14 Nafiysul Qodar, “Jessica:Keluarga Saya Dipojokkan dan Menderita, Saya Bingung”, http://news.liputan6.com/ $\mathrm{read} / 2624337 /$ jessica-keluarga-saya-dipojokkan-dan-menderita-saya-bingung, diakses 7 April 2017.

15 Pasal 5 ayat (1) Undang-Undang Republik Indonesia Nomor 40 Tahun 1999 tentang Pers: “(1) Pers nasional berkewajiban memberitakan peristiwa dan opini dengan menghormati norma-norma agama dan rasa kesusilaan masyarakat serta asas praduga tak bersalah.” 
mulai dari jalannya persidangan hingga gerak gerik Jessica pun turut dijadikan tolok ukur. Komentar para ahli yang dihadirkan oleh stasiun TV untuk berkomentar ini menimbulkan potensi persidangan oleh pers atau trial by press. Pendapat ahli pun turut menjadi sorotan penting. Salah satu ahli mengatakan bahwa pelaku yang meracuni Mirna ini cukup pintar karena menaruh sianida dalam air dingin bukan air panas. ${ }^{16}$ Pendapat ahli yang seperti ini menimbulkan potensi penggiringan opini yang mengarah langsung pada Jessica. Selain itu ada pula yang memberitakan tentang latar belakang Jessica selama di Australia. Dalam artikelnya mengatakan bahwa Jessica merupakan sosok yang sering bermasalah dengan penegak hukum Australia. ${ }^{17}$ Artikel ini sebenarnya tidak ada kaitannya dengan kasus yang dialami Jessica saat itu, namun eksploitasi berlebihan ini juga dapat menimbulkan opini masyarakat mengenai Jessica bahwa Jessica memang sering bermasalah dari masa lalunya, sehingga wajar saja jika Jessica merupakan pelaku sesungguhnya dalam kasus kopi sianida ini.

Wartawan Indonesia memiliki kode etik profesi wartawan yang disebut Kode Etik Wartawan Indonesia (KEWI). KEWI merupakan kode etik jurnalistik bersifat nasional yang ditetapkan oleh Dewan Pers dan telah disepakati oleh 26 organisasi wartawan pada 1999 Agustus. Berdasarkan pengaturan Pasal 7 ayat (1) UU Pers bahwa wartawan diberikan kebebasan dalam memilih organisasi wartawan. Praktiknya, masing-masing organisasi wartawan memiliki kode etik yang berbeda-beda. ${ }^{18}$ Perbedaan masing-masing kode etik inilah yang menjadi dorongan bagi Dewan Pers beserta ke-26 organisasi wartawan untuk membentuk sebuah kode etik yang bersifat nasional. Kendati demikian menurut Atmakusumah Astraatmadja ${ }^{19}$ keberadaan KEWI tidak mengurangi hak setiap organisasi wartawan dan perusahaan pers untuk memiliki kode etik jurnalistik bagi kepentingan anggota dan wartawannya sendiri.

KEWI juga memuat pengaturan mengenai pengutamaan asas praduga tak bersalah. Pengaturan terkait pengutamaan asas praduga tak bersalah, tercantum dalam Pasal $3 .^{20}$ Berdasarkan penjelasan KEWI Pasal 3 yaitu:

"Wartawan Indonesia dalam melaporkan dan menyiarkan

16 Liputan6.com, "ENAM PLUS: Menurut Saksi Ahli Pembunuh Mirna Pintar”, https://www.vidio.com/ watch/412607-enam-plus-menurut-saksi-ahli-pembunuh-mirna-pintar, diakses 17 Desember 2016.

17 Nurul Basmalah, "Melacak Masa Lalu Jessica Terdakwa Kasus Kopi Sianida di Australia”, http://global.liputan6. com/read/2573847/melacak-masa-lalu-jessica-terdakwa-kopi-sianida-di-australia?siteName=liputan6, diakses 17 Desember 2016.

18 AJI, “Kode Etik AJI", https://aji.or.id/read/kode-etik.html, diakses 1 April 2017. PWI dengan Peraturan Dasar Peraturan Rumah Tangga Kode Etik Jurnalistik PWI, Oemar Seno Adji, op.cit., lampiran, ATVSI yang merupakan organisasi yang beranggotakan seluruh TV Swasta di Indonesia, IJTI dengan Kode Etik Jurnalis Televisi Indonesia, dan lain-lain.

19 Alex Sobur, op.cit., hlm. 95.

20 Pasal 3 Kode Etik Wartawan Indonesia (KEWI): "Wartawan Indonesia menghormati asas praduga tak bersalah, tidak mencampurkan fakta dengan opini, berimbang dan selalu meneliti kebenaran informasi, serta tidak melakukan plagiat." 
informasi, tidak menghakimi atau membuat kesimpulan kesalahan seseorang, terlebih lagi untuk kasus-kasus yang masih dalam proses peradilan. Wartawan tidak memasukkan opini pribadinya. Wartawan sebaiknya, dalam melaporkan dan menyiarkan informasi perlu meneliti kembali kebenaran informasi. Dalam pemberitaan kasus sengketa dan perbedaan pendapat, masing-masing pihak harus diberikan ruang/waktu pemberitaan secara berimbang." 21

Asas praduga tak bersalah dalam pers, berakar dari asas praduga tak bersalah dalam KUHAP. Pengertian praduga tak bersalah dijelaskan dalam KUHAP pada penjelasan umum butir $3 \mathrm{c}$ KUHAP. ${ }^{22}$ Dari penjelasan umum butir 3c KUHAP, dapat ditarik sebuah kesimpulan bahwa tersangka dan terdakwa tidak boleh diberi label sebagai orang yang bersalah hingga terbit putusan pengadilan yang menyatakan kebersalahannya dan atas putusan tersebut telah memperoleh kekuatan hukum yang tetap, dalam artian tidak ada lagi proses banding, kasasi, maupun peninjauan kembali. Dapat dimengerti bahwa proses ini akan memakan waktu yang sangat lama meskipun pada asasnya bahwa peradilan harus cepat, sederhana dan biaya ringan. Proses yang lama inilah yang turut serta menjadi penyebab perbedaan pemaknaan asas praduga tak bersalah oleh pers. Dapat dibayangkan apabila seorang tersangka dan terdakwa dilarang untuk diberitakan hingga adanya putusan pengadilan tetap yang menyatakan kesalahannya. Hal ini akan bertentangan apabila berbicara persoalan hak warga negara seperti yang tercantum pada Pasal 28F Undang-Undang Dasar Negara Republik Indonesia Tahun 1945.23 Bahwa masyarakat juga berhak untuk mendapatkan informasi yang akurat dan berdasarkan fakta bukan opini yang menggiring.

Berbicara tentang fakta, pada dasarnya, hal yang diungkap oleh beberapa media merupakan fakta, meskipun ada beberapa media yang lebih senang dengan menambah bumbu dalam beritanya. ${ }^{24}$ Sebagai penjelasan, seseorang yang secara yuridis telah dikenai status tersangka, akan diberitakan oleh wartawan sebagai tersangka berdasarkan fakta yuridis bahwa orang tersebut memang telah ditetapkan sebagai tersangka oleh aparat penegak hukum. Wartawan akan memaparkan sejumlah fakta yuridis yang berhasil dihimpun kemudian dituliskan sebagai artikel. Kesalahan berdasarkan fakta, misalnya untuk kasus pembunuhan, bahwa seorang yang melakukan pembunuhan adalah orang yang mungkin berada di sekitar lokasi pembunuhan,

21 Penjelasan Pasal 3 KEWI.

22 Penjelasan umum Kitab Undang-undang Hukum Acara Pidana butir 3c: "Setiap orang yang disangka, ditangkap, ditahan, dituntut, dan/atau dihadapkan dimuka sidang pengadilan wajib dianggap tidak bersalah sampai adanya putusan pengadilan yang menyatakan kesalahannya dan memperoleh kekuatan hukum tetap."

23 Pasal 28F UUDNRI tahun 1945: Setiap orang berhak untuk berkomunikasi dan memperoleh informasi untuk mengembangkan pribadi dan lingkungan sosialnya, serta berhak untuk mencari, memperoleh, memiliki, menyimpan, mengolah, dan menyampaikan informasi dengan menggunakan segala jenis saluran yang tersedia.

24 Haryadi Suadi dalam Edy Susanto,dkk, op.cit., hlm. 13. 
maka orang tersebut patut dicurigai sebagai seorang yang disangka sebagai pembunuh. Fact guilt dan presumption of guilt merupakan dua dari kelima karakteristik yang diikuti oleh negara dengan crime control mode ${ }^{25}$ seperti Amerika Serikat. ${ }^{26}$ Jika dikembalikan lagi pada "Sepuluh Pedoman Penulisan tentang Hukum" dan KUHAP, maka penerapan yang seharusnya yaitu penggunaan asas praduga tak bersalah (presumption of innocence) yang berkaitan dengan konsep "legal guilt", tidak menggunakan asas praduga bersalah (presumption of guilt) yang berkaitan pada konsep "fact guilt". ${ }^{27}$ "Fact guilt" tidak sama dengan "legal guilt" 28 , karena bisa saja "fact guilt" namun ternyata "legal innocent". Maksudnya yaitu jika menggunakan konsep legal guilt, maka seseorang dianggap bersalah jika secara undang-undang memenuhi unsur kesalahan. Namun jika menggunakan konsep factual guilt, seseorang akan dinyatakan bersalah saat ditemukan sejumlah fakta yang ada bersama terduga dan bukti tersebut mengarah padanya. Maka dari itu, konsep factual guilt, sangat memungkinkan adanya legal innocent yang berarti seorang terduga itu ternyata tidak bersalah menurut hukum.

Pada penelitian ini digunakan beberapa teori sebagai pendukung gagasan penulis. Teori-teori yang digunakan yaitu teori kebebasan pers, teori kebijakan hukum pidana dan teori kebijakan kriminal. Teori kebebasan pers menjelaskan mengenai berbagai macam teori kebebasan pers yang dianut oleh berbagai negara di dunia. Teori kebebasan pers terdiri dari enam teori yaitu: The Authoritarian Press Theory, The Libertarian Press Theory, The Social Responsibility Press Theory, Soviet Communist Concept Theory ${ }^{29}$, Teori Pers Pembangunan, Teori Pers Partisipan Demokratik. ${ }^{30}$ Indonesia sendiri memiliki teori kebebasan yang mencerminkan jiwa bangsa, yaitu Teori Kebebasan Pers Pancasila. Selain menjelaskan tentang beberapa teori yang dianut di dunia, teori kebebasan pers juga digunakan untuk menganalisis kebebasan pers terkait asas praduga tak bersalah. Teori kebijakan hukum pidana dan kebijakan kriminal digunakan untuk menganalisis terkait fakta berdasarkan kasus bahwa KUHP bukan jalan satu-satunya bagi wartawan.

Permasalahan yang diangkat pada tulisan

25 Crime Control Model memiliki lima karakteristik tindakan represif terhadap suatu tindakan kriminal, efisiensi penegak hukum untuk melakukan seleksi tersangka merupakan perhatian utama, informal fact-finding, factual guilt, and presumption of innocence dikutip dari Romli Atmasasmita, Sistem Peradilan Pidana Kontemporer, (Jakarta: Kencana, 2011), hlm. 12.

26 Ibid., hlm. 9.

27 Ibid., hlm. 11.

28 Legal guilt memiliki konsep pemikiran yaitu: 1 . seseorang dianggap bersalah apabila penetapan kesalahannya dilakukan secara prosedural dan dilakukan oleh pihak yang berwenang. 2. seseorang tidak dapat dianggap bersalah sekalipun kenyataannya akan memberatkan jika perlindungan hukum yang bersangkutan tidak efektif., Ibid., hlm. 10.

29 Edy Susanto, dkk, op.cit., hlm. 23.

30 Hikmat Kusumaningrat dan Purnama Kusumaningrat, op.cit., hlm. 24. 
ini yaitu bagaimana asas yang seharusnya dipakai wartawan sebagai landasan untuk mempublikasikan perkara pidana dan bagaimana implikasi hukum apabila publikasi perkara pidana oleh wartawan bertentangan dengan asas praduga tak bersalah. Penelitian ini merupakan penelitian normatif dengan teknik analisis bahan hukum teknik interpretasi gramatikal dan sistematik.

\section{Pembahasan}

\section{A. Asas yang Seharusnya Dipakai Wartawan Sebagai Landasan untuk Mempublikasikan Perkara} Pidana

\section{Etika dan penafsiran wartawan terhadap asas praduga tak bersalah}

Etika berasal dari bahasa Yunani yaitu "ethos" yang dalam kalimat tunggal berarti adat atau kebiasaan. ${ }^{31}$ Istilah etika menjadi istilah teknis untuk ilmu pengetahuan yang menyelidiki soal-soal dan kaidah-kaidah kelakuan, serta perbuatan manusia. Jadi, jika istilah etika dibatasi pada asal-usul kata seperti yang disebutkan sebelumnya, maka etika dapat diartikan sebagai ilmu tentang hal yang biasa dilakukan manusia; atau ilmu tentang hal yang mempelajari adat kebiasaan. ${ }^{32}$ Batasanbatasan tersebut menjadi patokan dalam melakukan pendekatan terhadap pengertian etika. Berikut ini dirangkum beberapa pengertian etika menurut beberapa ahli:

a. Etika adalah teori tentang perbuatan manusia, yaitu ditimbang menurut baik dan buruknya.

b. Etika adalah ilmu pengetahuan tentang kesusilaan atau moral.

c. Etika adalah ilmu yang menyelidiki mana yang baik dan mana yang buruk dengan memperhatikan amal perbuatan manusia sejauh yang dapat diketahui oleh akal pikiran.

d. Etika adalah ilmu pengetahuan tentang asas-asas akhlak (moral)

e. Etika adalah bagian filsafat yang meliputi hidup baik, menjadi orang baik, berbuat baik, dan menginginkan hal-hal yang baik dalam hidup."

Etika yang akan dibahas berikut yaitu etika dari pers. Berdasarkan pengertian dari etika tersebut sebelumnya, maka etika pers adalah filsafat di bidang moral pers, yaitu bidang mengenai kewajiban-kewajiban pers dan tentang hal yang merupakan baik dan buruk, benar dan salah, serta tepat dan tidak tepat mengenai pers. ${ }^{33}$ Selain itu etika pers dapat diartikan sebagai sebuah ilmu atau tentang studi tentang peraturan-peraturan yang mengatur tingkah laku pers. Jadi, etika pers merupakan hal yang harus dilakukan oleh orang-orang yang terlibat dalam kegiatan pers. $^{34}$

Etika dirumuskan menjadi sebuah

31 Alex Sobur, op.cit., hlm. 3.

32 Ibid.

33 Ibid., hlm. 146.

34 Hikmat Kusumaningrat dan Purnama Kusumaningrat, op.cit., hlm. 34. 
peraturan yang mengikat. Etika pers khususnya wartawan dirumuskan dalam Kode Etik Wartawan Indonesia (KEWI). Dalam KEWI dirumuskan landasan bagi wartawan untuk bertindak dalam menjalankan tugasnya. Kode etik yang menjadi fokus dalam penelitian ini yaitu perihal penggunaan praduga tak bersalah oleh wartawan seperti yang tercantum dalam Pasal 3 KEWI. ${ }^{35}$

Penghormatan terhadap asas praduga tak bersalah diwajibkan pula pada wartawan dalam UU Pers Pasal 5 ayat (1). Bahkan dalam UU Pers Pasal 18 ayat (2), diberikan sanksi bagi perusahaan pers yang tidak menghormati asas praduga tak bersalah. Meskipun sanksi diberikan kepada perusahaan pers, tentu saja kesalahan mengenai pelanggaran terhadap aturan pada Pasal 5 ayat (1) tersebut tidak terlepas dari kesalahan wartawan yang tidak mematuhi kode etik.

Jika akhir-akhir ini banyak berita-berita yang sudah tidak melakukan penghormatan kepada asas praduga tak bersalah, hal ini semata-mata karena adanya perbedaan dalam hal cara menafsirkan asas praduga tak bersalah itu sendiri. Menurut Loebby Loqman, ${ }^{36}$ penafsiran asas praduga tak bersalah terbagi menjadi beberapa pendapat dan variasi. Beberapa pendapat ini yaitu:

a. Pendapat pertama yaitu wartawan tidak menyebutkan nama serta identitas atau gambar seorang tersangka.

b. Pendapat kedua yaitu asas praduga tak bersalah hanya berlaku bagi perkara yang sedang disidangkan di depan pengadilan, sehingga penyajian pemberitaan sebelum sampai ke depan pengadilan, tidak ada kewajiban bagi wartawan untuk merahasiakan identitas tersangka.

c. Pendapat ketiga, penyebutan nama lengkap, identitas ataupun gambar sangat dihindari dikecualikan dalam beberapa hal.

d. Pendapat lain yaitu memuat gambar tersangka/terdakwa dengan menutup matanya meskipun identitasnya dimuat secara lengkap atau dilakukan sebaliknya. Selain itu ada pula surat kabar yang semata-mata menggunakan pertimbangan-pertimbangan komersial dalam memutuskan ditulis atau tidaknya identitas terduga secara lengkap. ${ }^{37}$

Sejak awal proses, mulai dari pemeriksaan pendahuluan (dalam fase penyidikan), penuntutan dan persidangan dihadapan pengadilan, seharusnya orang tersebut tetap wajib dianggap tidak bersalah jika belum ada putusan yang dapat membuktikan kesalahannya dan memiliki kekuatan hukum yang tetap. Oemar Seno Aji memiliki pendapat

\footnotetext{
35 Pasal 3 Kode Etik Wartawan Indonesia (KEWI): "Wartawan Indonesia menghormati asas praduga tak bersalah, tidak mencampurkan fakta dengan opini, berimbang dan selalu meneliti kebenaran informasi, serta tidak melakukan plagiat."

36 Loebby Loqman, "Asas Praduga Tak Bersalah di dalam Pemberitaan oleh Media Massa”, Jurnal Dewan Pers Edisi No 2, (November 2010): 60, diakses 12 Februari 2016, http://dewanpers.or.id/FILE\%20LAMA/jurnal/ detail/128/jurnal-dewan-pers-edisi-ke-2.

37 Oemar Seno Aji, op.cit., hlm. 83.
} 
bahwa penggunaan asas praduga tak bersalah pada tingkat pemeriksaan pendahuluan, dikarenakan tingkat pemeriksaan pendahuluan merupakan fase tingkatan pemeriksaan yang sangat peka dan dapat diberlakukan asas tersebut secara penuh. ${ }^{38}$ Selain itu penggunaan kata-kata superlatif yang menunjukkan stigma, cap, stempel, atau keburukan orang juga dilarang untuk digunakan. Contohnya yaitu penyebutan seseorang sebagai "gembong narkoba", "penjahat kelas kakap", "si pembohong”, dan berbagai julukan kasar lainnya, merupakan kata-kata yang seringkali dianggap sebagai pelanggaran terhadap aturan penghormatan kepada asas praduga tak bersalah. Pemberian stigma "gembong" kepada orang sebelum terbitnya putusan pengadilan, dikhawatirkan dapat mengakibatkan terjadinya pengadilan oleh pers (trial by press).

Dalam hal tertentu asas praduga tak bersalah saling berbenturan dengan kebebasan pers. Di satu pihak, tersangka/terdakwa kasus pidana memerlukan persidangan yang terbuka untuk umum agar pihak yang berwenang tidak bertindak diluar batas kewenangannya. Akan tetapi, persidangan yang terlalu terbuka dapat memberikan efek berbalik arah bagi tersangka/terdakwa itu sendiri. Stigma dan trial by press menjadi salah satu akibat dari terbukanya sidang untuk umum secara berlebihan. Hal inilah yang bertentangan secara langsung dengan praduga tak bersalah. Pemberitaan atau peliputan yang terlalu bebas membawa masyarakat kedalam sebuah pemikiran bahwa tersangka/terdakwa benarbenar bersalah. Publikasi yang berlebihan juga dapat menyebabkan tersangka/terdakwa beserta keluarganya mendapatkan sanksi sosial yang lebih berat dibanding sanksi pidana misalnya sanksi pengucilan, rusaknya reputasi dan lain sebagainya. Persidangan yang terbuka untuk umum memang harus dilakukan dalam kondisi tertentu, sehingga kepentingan masyarakat akan sebuah pers bebas akan terpenuhi disamping pemenuhan hak tersangka untuk mendapatkan proses hukum yang adil. Namun, kebebasan pers ini tetap harus diberikan batasan sehingga tidak mengakibatkan trial by press. Trial by press bertentangan dengan prinsip prosedur hukum yang adil dan melanggar penghormatan terhadap praduga tak bersalah. ${ }^{39}$

\section{Asas pada publikasi pemberitaan perkara pidana oleh wartawan}

Penggunaan asas praduga tak bersalah pada bidang praktek pers diartikan dalam berbagai kondisi yang berbeda-beda dari asas praduga tak bersalah dalam pemaknaan secara hukum. Asas praduga tak bersalah dalam praktek pers, terdapat tiga pemaknaan yaitu:

a. Asas praduga tak bersalah dalam praktek pers dapat dimaknai sebgai upaya penyelenggaraan kontrol sosial yang 
menghindari adanya trial by the press. ${ }^{40}$

b. Asas praduga tak bersalah dalam praktek pers dimaknai sebagai kesadaran bahwa penghakiman merupakan penodaan nilainilai demokrasi yang menjunjung tinggi kebebasan. ${ }^{41}$

c. Asas praduga tak bersalah dalam praktek pers dimaknai sebagai pelaksanaan fungsi pers meningkatkan kesadaran hukum masyarakat dan penghormatan atas supremasi hukum. ${ }^{42}$

Sebenarnya, dalam melakukan pemberitaan dimedia, wartawan menggunakan asas praduga bersalah. Dapat dikatakan seperti itu karena dalam melakukan pemberitaan, wartawan mendasari beritanya berdasarkan fakta. Namun pemberitaan berdasarkan fakta ini harus tetap berada dalam wilayah asas praduga tak bersalah. Jadi, meskipun wartawan menggunakan fact guilt sebagai dasar pemberitaan, namun harus diimbangi dengan hak jawab dan pemberitaan yang berimbang sebagai bentuk penghormatan terhadap asas praduga tak bersalah.

\section{B. Implikasi Hukum Apabila Publikasi Perkara Pidana oleh Wartawan Bertentangan dengan Asas Praduga tak Bersalah}

\section{Delik penghinaan/pencemaran oleh pers}

Publikasi perkara pidana oleh wartawan yang bertentangan dengan asas praduga tak bersalah dinilai telah mencederai kehormatan korban. Implikasi hukum dari tindakan ini adalah wartawan dapat dipidana dengan pasalpasal KUHP pada tindak pidana penghinaan/ pencemaran pada umumnya. Dalam KUHP, masalah kejahatan kepada nama baik atau kehormatan diatur pada Pasal 310-321. Terdapat empat klasifikasi jenis kejahatan yang ditunjukkan terhadap kehormatan dalam bentuk murni, yaitu menghina secara lisan (smaad), menghina secara tertulis (smaad schrift), memfitnah (laster), dan menghina secara ringan (eenvoudige belediging). Sedangkan apabila ditinjau dari Pasal 310 KUHP, media penghinaan/pencemaran alat dibedakan menjadi penghinaan/pencemaran secara lisan (slander) atau penghinaan/ pencemaran secara tertulis atau barang cetakan (libel). ${ }^{43}$

Pada dasarnya, pelanggaran atau kejahatan terhadap nilai-nilai luhur kehormatan atau nama baik seseorang atau lembaga resmi, terletak dan bergantung terhadap cara dari tindakan itu dikerjakan. Suatu pemberitaan, misalnya, pada delik penghinaan atau pencemaran nama baik, perlindungan korban

\footnotetext{
40 Chairul Huda, "Makna Asas Praduga Tidak Bersalah dan Pemakaiannya dalam Praktek Pers", Jurnal Dewan Pers Edisi No 2, (November 2010): 89, http://dewanpers.or.id/FILE\%20LAMA/jurnal/detail/128/jurnaldewan-pers-edisi-ke-2, diakses 12 Februari 2016.

41 Ibid.

42 Ibid.

43 Alex Sobur, op.cit., hlm. 390.
} 
sudah diatur dalam KUHP. Oleh karena itu, setiap orang yang merasa bahwa dirinya dihina atau dicemarkan nama baiknya dapat mengadukan tindakan tersebut melalui jalur hukum.

Penghinaan / pencemaran menurut pembagian ilmu hukum dibagi menjadi dua, yaitu penghinaan/pencemaran formil dan penghinaan/pencemaran materiil. ${ }^{44}$ Berikut penjelasan mengenai penghinaan/pencemaran materiil dan penghinaan/pencemaran formil.

\section{a. Penghinaan/pencemaran Materiil}

Penghinaan/pencemaran berdasarkan isi dari suatu fakta yang meliputi pernyataan singkat dan padat yang dikemas dalam kata-kata baik secara lisan maupun tertulis. Faktor untuk menentukan sebuah perbuatan itu termasuk dalam penghinaan/pencemaran materiil atau tidak yaitu isi dari pernyataan baik secara tertulis ataupun lisan. Cara yang digunakan untuk menyampaikan penghinaan/ pencemaran materiil yang secara halus dan singkat ini, masih memiliki kemungkinan untuk pembuktian tentang kebenaran dari tuduhan yang dilakukan serta membuktikan bahwa tujuan dilakukannya penghinaan/ pencemaran secara materiil tersebut demi kepentingan umum atau karena terpaksa membela diri. Sebagai contohnya sindiran bagi pengacara Jessica dalam sebuah berita elektronik yang menyebutkan bahwa tanpa Otto Hasibuan, pengacara Jessica jadi bahan tertawaan. ${ }^{45}$ Headline berita yang disebutkan seperti ini, diasumsikan penulis bahwa tanpa Otto Hasibuan yang saat itu memang tidak bisa hadir, pengacara Jessica bukan pihak yang harus dihormati.

\section{b. Penghinaan/pencemaran Formil}

Penghinaan / pencemaran formil menekankan pada cara pernyataan itu disampaikan. Faktor yang menentukan dari penghinaan/pencemaran bentuk formil ini yaitu cara dan bentuk penyampaian penghinaan/pencemaran tersebut. ${ }^{46}$ Berbeda dengan penghinaan/pencemaran materiil yang dalam penyampaiannya dilakukan secara halus, penghinaan/pencemaran formil disampaikan dengan cara menyerang secara kasar.

Untuk menentukan sebuah perbuatan itu termasuk penghinaan/pencemaran atau bukan, harus diketahui dan dianalisis melalui unsurunsur yang terdapat pada Pasal 310 KUHP. ${ }^{47}$ Penghinaan/pencemaran yang dikatakan sebagai delik pers yaitu Pasal 310 ayat (2) KUHP. Pasal 310 ayat (2) KUHP tentang

44 Oemar Seno Adji, Perkembangan Delik Pers di Indonesia, (Jakarta: Erlangga, 1990), hlm. 37.

45 Nafiysul Qadar, “Tanpa Otto Hasibuan Pengacara Jessica Jadi Tertawaan”, http://news.liputan6.com/ read/2608126/tanpa-otto-hasibuan-pengacara-jessica-jadi-tertawaan, diakses 27 Januari 2017.

46 Oemar Seno Adji, op.cit., hlm. 39.

47 Lihat Pasal 310 KUHP: “ (1) barangsiapa sengaja menyerang kehormatan atau nama baik seseorang, dengan menuduh sesuatu hal, yang maksudnya terang supaya hal itu diketahui umum, diancam, karena pencemaran, dengan pidana penjara paling lama sembilan bulan atau denda paling banyak tiga ratus rupiah. (2) jika hal itu dilakukan dengan tulisan atau gambaran yang disiarkan, dipertunjukkan atau ditempelkan di muka umum, maka yang bersalah, karena pencemaran tertulis, diancam pidana penjara paling lama satu tahun empat bulan atau denda paling banyak tiga ratus rupiah. (3) tidak merupakan pencemaran atau pencemaran tertulis, jika perbuatan terang dilakukan demi kepentingan umum atau karena terpaksa untuk bela diri.” 
Penghinaan/pencemaran tertulis, adalah pasal yang banyak digunakan sebagai dasar hukum oleh penegak hukum untuk dikenakan pada wartawan. ${ }^{48}$ Namun seharusnya, kasus Penghinaan/pencemaran oleh wartawan, tidak boleh semerta-merta dijerat dengan Pasal 310 ayat (2) KUHP sebagai alasan wartawan melakukan publikasi.

Pasal 310 KUHP ini seringkali dikaitkan dengan Pasal 315 KUHP yang diartikan sebagai menyerang kehormatan atau nama baik "aanranding of goede naam" yang menimbulkan klasifikasi legislatif antara pencemaran tertulis (smaadshcriff) dan Penghinaan/pencemaran/pencemaran ringan pada Pasal 315 KUHP. ${ }^{49}$ Jika sering dikaitkan, maka tak jarang memiliki kerancuan. Oleh karena itu Pasal 310 dan Pasal 315 KUHP ini diberikan perbedaan. Menurut Oemar Seno Adji, ${ }^{50}$ tiga perbedaan itu juga akan menimbulkan akibat hukum yang berbeda pula, yaitu:

a. Charge with an act or fact yaitu adanya tuduhan orang pada orang lain karena melakukan suatu perbuatan atau hal. Tuduhan ini merupakan suatu persyaratan bagi Penghinaan/pencemaran biasa yang tidak ditemukan pada delik Penghinaan/ pencemaran ringan (Pasal 315 KUHP).

b. Plea of justification yang dapat diajukan pada penghinaan/pencemaran biasa. Sedangkan plea of justification tidak terdapat dalam penghinaan/pencemaran ringan.

c. Pasal 310 ayat (3) KUHP dikualifikasikan sebagai "fait'd excuse" (alasan pemaaf) dan sering dalam suatu delik pers dipergunakan sebagai suatu landasan untuk mengadakan beroep (banding) karena dianggap tidak ada pencemaran tertulis. Hal ini jelas, karena pada Pasal 315 KUHP diterangkan jika perbuatan itu dilakukan demi kemslahatan bersama atau terpaksa karena melakukan pembelaan diri, maka perbuatan tersebut tidak dapat dikategorikan pencemaran atau pencemaran tertulis. Beroep hanya bisa dilakukan jika memenuhi unsur dalam Pasal 310 KUHP tentang penghinaan/pencemaran biasa dan tidak dapat menjadi landasan pada Pasal 315 KUHP tentang penghinaan/pencemaran ringan.

Banyaknya kasus yang melibatkan wartawan yang dijerat dengan Pasal 310 ayat (2) KUHP merupakan konflik tersendiri yang patut dikaji. Padahal wartawan, yang berkapasitas sebagai seorang jurnalis, seharusnya tidak bisa dengan mudah dijerat menggunakan Pasal 310 ayat (2) KUHP. Hal ini disebabkan wartawan masih terikat kode etik yang jika wartawan melakukan pelanggaran, harusnya disidang terlebih dahulu secara etik. Contoh kasus yaitu kasus pemimpin redaksi 
harian Rakyat Merdeka, Karim Paputungan yang divonis lima bulan penjara oleh hakim Pengadilan Negeri Jakarta Selatan pada tanggal 9 September 2003 setelah dinyatakan bersalah telah melanggar Pasal 310 ayat (2) KUHP. Kasus ini diajukan ke pengadilan sebagai akibat pemuatan foto parodi Akbar Tanjung di Harian Rakyat Merdeka edisi 8 Januari 2002 yang memperlihatkan bagian tubuh bertelanjang dada dan penuh keringat. Foto ini merupakan ilustrasi dari berita berjudul "Akbar Sengaja Dihabisi. Golkar Nangis Darah". Selain kasus ini, adapula kasus yang melibatkan pemimpin umum majalah berita Tempo dan atas kantor majalah Tempo. Hakim Pengadilan Negeri Jakarta Pusat memerintahkan dilakukannya sita jamin atas rumah tinggal Gunawan Muhamad sebagai respon atas pengaduan bos Grup Artha Graha, Tomy Winata sehubungan dengan pernyataan Gunawan yang menyatakan “... Jangan sampai Republik ini jatuh ke tangan preman." Pernyataan ini dianggap Tommy sebagai pencemaran nama baiknya. ${ }^{51}$ Sita jamin atas kantor Tempo dilakukan untuk menindaklanjuti vonis terhadap Pemimpin Redaksi Tempo, Bambang Harimurti dan dua wartawan Tempo Ahmad Tengku dan Tengku Iskandar Ali yang diadukan Tommy atas tuduhan pemuatan berita bohong Majalah Tempo berjudul "Ada Tommy di Tenabang".
Kasus kedua ini juga divonis Pasal 310 ayat (2) KUHP.

\section{Kebijakan pengaturan pada wartawan terkait pelanggaran asas praduga tak bersalah}

UU Pers, mengatur mengenai pemidanaan Pers yang tidak menghormati asas praduga tak bersalah, seperti dirumuskan dalam Pasal 5 ayat (1) dan Pasal 18 ayat (2). ${ }^{52}$ Pada Pasal 5 ayat (1), yang menjadi subjek yang diatur adalah pers nasional. Menurut Pasal 1 butir 6, pers nasional adalah pers yang terselenggara oleh perusahaan pers di Indonesia. Sedangkan jika dikaitkan dengan Pasal 1 butir 1, pers adalah lembaga sosial dan tempat pertukaran informasi serta sebagai wahana komunikasi massa yang melaksanakan kegiatan jurnalistik. Selanjutnya mengenai Pasal 18 ayat (2) yang mengatur tentang sanksi, subjek yang diatur adalah perusahaan pers. Berdasarkan Pasal 1 butir 2, perusahaan pers adalah badan hukum Indonesia yang menyelenggarakan suatu usaha berbentuk pers. Berdasarkan penjelasan ini, dapat disimpulkan bahwa pengaturan pada UU Pers ini hanya mengatur tentang pers dan perusahaan pers, tidak mengatur tentang wartawan atau jurnalis. Wartawan tidak tersentuh sama sekali dengan UU Pers ini. Timbul permasalahan apabila seorang jurnalis melakukan pelanggaran terhadap penghormatan asas praduga tak bersalah.

51 Hikmat Kusumaningrat dan Purnama Kusumaningrat, op.cit., hlm. 43.

52 Lihat Pasal 5 ayat (1) dan Pasal 18 ayat (2) UU Pers: "Pasal 5: (1) Pers nasional berkewajiban memberitakan peristiwa dan opini dengan menghormati norma-norma agama dan rasa kesusilaan masyarakat serta asas praduga tak bersalah" "Pasal 18 (2): Perusahaan pers yang melanggar ketentuan Pasal 5 ayat (1) dan ayat (2), serta Pasal 13, dipidana dengan pidanan denda paling banyak Rp. 500.000.000,00 (lima ratus juta rupiah).” 
Sebagai akibat belum diaturnya tindak pidana Penghinaan/pencemaran oleh wartawan dalam UU Pers, aparat penegak hukum menggunakan Pasal 310 ayat (2) KUHP sebagai delik pers. Banyak peristiwa mengenai wartawan yang dijerat dengan Pasal 310 ayat (2) KUHP. Hal ini mengakibatkan fungsi Dewan Pers berupa memberikan pertimbangandanmengupayakanpenyelesaian pengaduan masyarakat atas kasus-kasus yang berhubungan dengan pemberitaan pers, jadi terlewatkan. ${ }^{53}$ Hal ini kemungkinan besar terjadi karena ketika terjadi perkara Penghinaan/pencemaran, masyarakat tidak menyelesaikan lewat Dewan Pers melainkan langsung melakukan pengaduan pada aparat penegak hukum. Harusnya, ketika seorang wartawan melakukan sebuah pelanggaran yang masih dalam fungsi profesinya, maka terlebih dahulu ditindaklanjuti berdasarkan undang-undang yang mengatur tentang profesinya, bukan berdasarkan KUHP. Permasalahan ini akan terus berlanjut dan tidak ada pemecahannya hingga dirumuskan sebuah peraturan yang memang khusus mengatur tentang permasalahan ini. Maka dari itu diperlukan sebuah pembaharuan hukum di bidang hukum pidana guna mengadakan pembaruan pengaturan hukum pada hukum pidana pers ini.

Pembaruan hukum pidana merupakan bagian dari kebijakan hukum pidana. Definisi kebijakan hukum pidana adalah suatu usaha untuk mewujudkan peraturan perundangundangan pidana yang sesuai dengan keadaan dan situasi masa suatu waktu dan untuk masamasa yang akan datang.
"Mewujudkan sebuah peraturan perundang-undangan merupakan salah satu usaha rasional yang dapat dilakukan oleh masyarakat dalam menanggulangi kejahatan. Usaha rasional tersebut merupakan definisi singkat dari kebijakan kriminal. Maka dari itu kebijakan hukum pidana merupakan bagian dari kebijakan kriminal. Jadi berdasarkan penyataan tersebut dapat ditarik sebuah kesimpulan berupa untuk melakukan pembaharuan hukum pidana dapat dilakukan dengan mengadakan kebijakan kriminal."${ }^{54}$

Kebijakan kriminal memiliki masalah sentral yang biasa disebut kriminalisasi diharuskan memenuhi beberapa kriteria sebagai berikut:

a. Apakah perbuatan itu tidak disukai atau dibenci oleh masyarakat karena merugikan, atau dapat merugikan, mendatangkan korban atau dapat mendatangkan korban. Namun, Penghinaan/pencemaran yang dilakukan oleh wartawan merupakan hal yang berbeda dengan Penghinaan/pencemaran yang terdapat pada Pasal 310 ayat (2) KUHP. Penghinaan/pencemaran oleh media memberikan dampak yang lebih luas karena bersifat permanen

53 Meskipun hak jawab dan upaya mediasi yang dilakukan oleh Dewan Pers tidak menghapuskan pertanggungjawaban pidana pelaku tindak pidana pers, namun upaya tersebut tetap harus diljalankan terlebih dahulu dengan perantara Dewan Pers. Adami Chazawi, dkk, Tindak Pidana Pers (Penyerangan Terhadap Kepentingan Hukum, (Bandung: Mandar Maju, 2015), hlm. 209.

54 Barda Nawawi Arief, Bunga Rampai Kebijakan Hukum Pidana, (Jakarta: Kencana Prenada Media Group, 2011), hlm. 3. 
dibandingkan dengan Penghinaan/ pencemaran yang dilakukan oleh masyarakat biasa yang menggunakan media massa sebagai sarana untuk menyalurkan tulisan yang berisi hinaan tersebut.

b. Apakah biaya mengkriminalisasi seimbang dengan hasilnya yang akan dicapai, artinya cost pembuatan undangundang, pengawasan dan penegakkan hukum, serta beban yang dipikul oleh korban, pelaku, dan kejahatan itu sendiri harus seimbang dengan situasi tertib yang akan dicapai. Biaya pastinya meningkat, karena akan ada pekerjaan baru bagi aparat penegak hukum. Maka dari itu tidak dapat dikatakan seimbang antara biaya kriminalisasi dan hasil yang dicapai.

c. Apakah akan menambah beban aparat penegak hukum yang tidak seimbang atau nyata-nyata tidak dapat diemban oleh kemampuan yang dimilikinya. Kriminalisasi terhadap pers, sudah pasti akan menambah beban bagi aparat penegak hukum. Maka dari itu, kebanyakan kasus yang terjadi, aparat penegak hukum terkesan asal dalam menerapkan pasal. Hal inilah yang memicu banyaknya aparat penegak hukum menggunakan Pasal 310 ayat (2) KUHP yang sebenarnya bukan merupakan delik pers. d. Apakah perbuatan-perbuatan itu menghambat atau menghalangi cita-cita bangsa, sehingga merupakan bahaya bagi keseluruhan masyarakat. Perbuatan Penghinaan/pencemaran tentu saja menimbulkan bahaya bagi masyarakat. Kebebasan pers merupakan kebebasan yang bertanggung jawab sosial, bukan kebebasan pers yang sebebas-bebasnya, sehingga harus diadakan pembatasan agar tidak terlewat batas. Meskipun kebebasan telah dilindungi secara konstitusional, namun, kebebasan yang menimbulkan pelanggaran hukum, secara otomatis telah melanggar hak asasi pribadi lain.

Wartawan dalam melakukan tugasnya, terikat oleh kode etik yang disebut Kode Etik Wartawan Indonesia. Ada penyelesaian yang sudah terkoridor yang alangkah lebih baik jika dilakukan terlebih dahulu. Koridor yang dimaksud yaitu dilakukan sesuai dengan bagaimana profesinya mengatur. Hal ini wajib diperhatikan karena ketika melakukan sebuah pelanggaran terhadap penghormatan asas praduga tak bersalah yang berujung Penghinaan/pencemaran, wartawan masih bekerja dengan kapasitas sebagai seorang wartawan. Ketika terjadi pelanggaran maka harusnya diselesaikan terlebih dahulu secara etik. Penyelesaian secara etik, harus terlebih dahulu diselesaikan dalam persidangan kode etik oleh Dewan Pers. ${ }^{55}$ Memang, sanksi yang

55 Persidangan kode etik tidak menghapuskan sanksi pidana diluar UU pers, namun, untuk sampai pada pemidanaan berdasar KUHP, disarankan untuk melalui hak jawab dan mediasi oleh Dewan Pers atau tim Ombudsman yang dimiliki oleh perusahaan pers. Selain itu untuk mencapai pemidanaan berdasar KUHP, seharusnya memenuhi tiga syarat yaitu pertama korban harus menggunakan hak jawab; kedua korban dan pers harus melakukan mediasi dengan perantara Dewan Pers; ketiga jika mediasi gagal, baru dilaksanakan pemidanaan berdasar KUHP. Adami Chazawi, dkk, loc.cit. 
digunakan pada Pasal 310 ayat (2) KUHP menggunakan jenis pidana alternatif (pidana penjara atau denda). Namun berdasarkan dari sekian kasus yang telah dicontohkan sebelumnya, hakim lebih cenderung menggunakan pidana penjara pada wartawan. Kecenderungan penggunaan pidana penjara oleh hakim, tidak sejalan dengan anggapan bahwa hukum pidana sebagai ultimum remedium. ${ }^{56}$

Pengaturan penghinaan / pencemaran memang telah diatur dalam Pasal 310-315 KUHP. Namun tidak semua korban perkara penghinaan / pencemaran melakukan pengaduan kepada aparat penegak hukum. ${ }^{57}$ Sistem peradilan pidana tidak lagi menjadi jalan satu-satunya yang dipilih korban untuk menyelesaikan kasus tindak pidana penghinaan/pencemaran. Hal ini menimbulkan sebuah gagasan untuk menyelesaikan perkara penghinaan/pencemaran di luar pengadilan. Selain itu, cara penyelesaian perkara di luar pengadilan merupakan salah satu bentuk dari sekian banyak perwujudan keadilan restoratif. Keadilan restoratif memiliki empat gagasan dan prinsip yang dapat menggambarkan wujud keadilan restoratif:

(1) Membangun partisipasi bersama-sama antara pelaku, korban, dan kelompok masyarakat untuk menyelesaikan suatu peristiwa atau tindak pidana.
Menempatkan pelaku, korban, dan masyarakat sebagai "stakeholders" yang bekerja sama dan langsung berusaha menemukan penyelesaian yang dipandang adil bagi semua pihak.

(2) mendorong pelaku bertanggung jawab terhadap korban atas peristiwa atau tindak pidana yang telah menimbulkan cidera, atau kerugian terhadap korban serta membangun tanggungjawab tidak menanggulangi lagi perbuatan pidana yang pernah dilakukannya.

(3) Menempatkan peristiwa atau tindak pidana tidak terutama sebagai suatu bentuk pelanggaran hukum, melainkan sebagai pelanggaran oleh seseorang/ sekelompok terhadap seorang/kelompok. Karena itu sudah semestinya pelaku perlu diarahkan pada pertanggungjawaban terhadap korban, bukan mengutamakan pertanggung jawaban hukum.

(4) Mendorong menyelesaikan suatu peristiwa atau tindak pidana dengan caracara informal dan personal, daripada penyelesaian melalui cara-cara formal dan impersonal. ${ }^{58}$

Sebagai salah satu bentuk perwujudan keadilan restoratif, penyelesaian perkara pidana mulai diperkenalkan kepada sebuah sistem yang merupakan adaptasi dari dimensi privat (perdata) ke ranah publik (pidana). Alternative Dispute Resolution (ADR) adalah suatu pranata penyelesaian sengketa diluar pengadilan yang mekanismenya berdasarkan sebuah kesepakatan para pihak dengan mengesampingkan penyelesaian sengketa

56 Van Bemmelen dalam Andi Hamzah, Asas-Asas Hukum Pidana, (Jakarta: Rineka Cipta, 1994), hlm. 10.

57 Hal ini terjadi pada kasus pemberitaan oleh Jawa Pos yang dinilai menghina tokoh-tokoh NU dan organisasi NU dengan judul pemberitaan "KKN di Sekitar Pemerintahan Gus Dur". NU lebih memilih jalur mediasi dengan perantara tim Ombudsman yang dibentuk oleh Jawa Pos dan berakhir dengan menghasilkan beberapa kesepakatan. Prija Djatmika, op.cit., hlm. 139.

58 Prija Djatmika, op.cit., hlm. 111. 
secara litigasi di pengadilan, baik dilakukan dengan cara konsultasi, negosiasi, mediasi, konsiliasi, atau penilaian ahli. ${ }^{59}$

Salah satu bentuk ADR yaitu mediasi. Mediasi memiliki karakteristik dan bentuk utama sebagai berikut: ${ }^{60}$

a. Mediasi diselenggarakan dengan cara yang tidak formal. Maksudnya yaitu para pihak tidak perlu terlalu kaku seperti ketika berada dipengadilan.

b. Mediasi diadakan untuk mencapai mufakat para pihak.

c. Pihak ketiga yang dipilih merupakan mediator yang dengan/tanpa keahlian dalam bidang yang disengketakan.

d. Mediasi berlangsung tertutup.

e. Hasil akhir dari mediasi berupa kesepakatan para pihak. Sifat kesepakatan ini final dan mengikat para pihak dan harus dilaksanakan dengan itikad baik

Dalam mediasi untuk menyelesaikan kasus Penghinaan/pencemaran oleh wartawan, pihak yang menjadi mediator yaitu Dewan Pers. ${ }^{61}$ Dewan Pers mencoba mengaplikasikan prinsip kekeluargaan dan musyawarah untuk mufakat dalam menangani kasus Penghinaan/ pencemaranyang disebabkan oleh pemberitaan oleh wartawan. Sebagai mediator, Dewan Pers akan mencoba menengahi kepentingan pihak pengadu dan pihak teradu yang dipertemukan dalam sebuah forum hingga bertemu suatu kesepakatan yang akan dituangkan dalam Pernyataan Perdamaian kedua belah pihak. Selain Dewan Pers, beberapa lembaga penerbitan pers seperti Jawa Pos dan Kompas, membentuk lembaga ombudsman yang salah satu tugasnya adalah menjadi pihak mediator internal untuk menyelesaikan perkara pemberitaan pers antara pihak redaksi pers yang bersangkutan dengan pihak-pihak yang merasa dirugikan dengan pemberitaan tertentu. ${ }^{62}$

Mediasi penal atau penyelesaian perkara pidana melalui cara mediasi, sesungguhnya sudah banyak diperkenalkan dalam berbagai peraturan perundang-undangan di Indonesia, salah satunya diperkenalkan dalam konsep diversi pada Undang-Undang Sistem Peradilan Pidana Anak. Hakikat mediasi penal dikembangkan dengan bertolak dari ide dan prinsip kerja sebagai berikut :63

a. Penanganan konflik: tugas mediator yaitu menghindarkan para pihak dari kerangka hukum dan mendorong untuk terlibat dalam sebuah komunikasi yang lebih intens. Hal ini didasarkan pada sebuah ide, bahwa kejahatan telah menyebabkan konflik interpersonal. Konflik inilah yang menjadi tujuan dari proses mediasi.

b. Berorientasi pada proses: mediasi penal lebih terorientasi pada kualitas proses dibandingkan hasilnya, yaitu: memberikankesadaran padapelaku tindak

59 Rachmadi Usman, Mediasi Di Pengadilan (Dalam Teori dan Praktik), (Jakarta: Sinar Grafika, 2012), hlm. 10. 60 Ibid., hlm. 12.

61 Prija Djatmika, Mediasi Penal Untuk Penyelesaian Perkara Penghinaan Oleh Pers, (Malang: Selaras, 2014), hlm. 121.

62 Ibid.

63 Lilik Mulyadi, Mediasi Penal Dalam Sistem Peradilan Pidana di Indonesia, (Bandung: Alumni, 2015), hlm. 35. 
pidana akan kesalahannya, kebutuhankebutuhan konflik terpecahkan, rasa tenang pada korban dari rasa takut, dan sebagainya.

c. Proses informal: mediasi penal adalah sebuah proses informal, tidak bersifat birokratis, serta menghindari prosedur hukum yang ketat.

d. Adanya partisipasi aktif dan otonom pada pihak: para pihak tidak dilihat sebagai objek dari prosedur hukum pidana, akan tetapi lebih dilihat sebagai subjek yang memiliki tanggung jawab pribadi serta kemampuan untuk bertindak. Dari keadaan ini, diharapkan pihak yang terlibat dapat berbuat atas kemauannya sendiri.

Bentuk mediasi penal ada bermacammacam. Berdasarkan rekomendasi Dewan Eropa No. R. (99) 19 dalam "Explanation Memorandum" tentang Mediation in Penal Matters, mediasi penal terdiri dari enam model yaitu: ${ }^{64}$

a. Model informal mediation: model ini dilakukan oleh personil peradilan pidana dalam tugas normalnya. Tugas ini dapat dilakukan oleh Jaksa Penuntut Umum dengan mengundang para pihak untuk menyelesaikan secara informal. Model ini memiliki tujuan untuk tidak meneruskan proses penuntutan apabila kesepakatan tercapai.

b. Model traditional village or tribal moots: menurut model ini, seluruh masyarakat dipertemukan dalam sebuah forum untuk memecahkan konflik kejahatan diantara warganya. Model ini dianut pada beberapa negara yang kurang maju dan negara yang berada di wilayah pedesaan/ pedalaman.

c. Model victim-offender mediation: model ini melibatkan berbagai pihak yang bertemu dalam sebuah forum dengan dihadiri oleh mediator yang telah ditunjuk sendiri oleh kedua belah pihak. Mediatornya bisa berasal dari pejabat formal, mediator independen, atau bahkan kombinasi dari pejabat formal dan mediator independen.

d. Model reparation negotiation programs: model ini digunakan saat penilaian kompensasi yang harus dibayarkan oleh pelaku tindak pidana kepada korban. Model ini biasa dilakukan saat pemeriksaan di pengadilan.

e. Model community panel of courts: model iniadalah sebuah program yang diciptakan untuk mengalihkan kasus pidana dari penuntutan atau peradilan. Pengalihan yang dimaksud yaitu pengalihan kepada prosedur masyarakat yang lebih fleksibel dan informal serta lebih melibatkan unsur mediasi atau negosiasi.

f. Model family and community group conferences: model ini telah mulai dikembangkan di Australia dan New Zealand, yang banyak melibatkan partisipasi masyarakat dalam sistem peradilan pidana.

Berdasarkan model-model mediasi

64 T. Gayus Lumbuun, Alternatif Dispute Resolution di dalam Sistem Peradilan Pidana, (Jakarta: Makalah Workshop, 2007), hlm. 36. 
penal yang telah disebutkan sebelumnya, sangat dimungkinkan perkara Penghinaan/ pencemaran oleh wartawan diselesaikan dengan menggunakan mediasi penal dengan Model victim-offender mediation, Model informal mediation dan Model community panel of courts. Alasan dipilihnya model informal mediation adalah personil masih terlibat langsung dalam proses peradilan pidana karena model ini memiliki tujuan untuk mencapai kesepakatan tidak melanjutkan perkara dalam proses peradilan pidana. Alasan memilih model victim-offender mediation adalah model ini yang mendekati dengan kebiasaan mediasi penal dalam Pers. Hadirnya mediator yang berasal dari pejabat formal, independen atau kombinasi, dapat disejajarkan dengan kehadiran Dewan Pers dan Ombudsman sebagai mediator. Selain itu, model ini lebih fleksibel karena dapat dilakukan pada setiap tahap proses peradilan pidana. Dengan demikian kemungkinan untuk berdamai lebih besar karena tidak perlu sampai masuk dalam pengadilan untuk mencapai kata damai. Untuk model community panel of courts dipilih karena model ini mengalihkan sistem peradilan pidana kepada prosedur masyarakat yang lebih mudah dipahami dan biasanya melibatkan organisasi masyarakat yang berpengaruh besar dalam lingkungan masyarakat tersebut.

\section{Simpulan}

Berdasarkan pembahasan tersebut diatas, dapat ditarik kesimpulan sebagai berikut:
1. Penghormatan kepada asas praduga tak bersalah oleh wartawan telah menyimpang dari makna sesungguhnya. Kini, wartawan lebih condong untuk menggunakan asas praduga bersalah dalam melakukan pemberitaan perkara pidana khususnya. Hal ini yang sangat berbahaya baik bagi wartawan itu sendiri maupun pihak yang diberitakan.

2. Implikasi hukum dapat terlihat dari bahaya-bahaya yang dapat timbul sebagai akibat pemberitaan perkara pidana yang tidak berkesesuaian dengan asas praduga tak bersalah. Bahaya bagi pihak yang diberitakan yaitu jika pemberitaan negatif itu salah, namun sudah terlanjur tersebar di masyarakat, pihak yang diberitakan itu akan mengalami stigma. Selain itu, ada pula trial by press sebagai akibat dari pemberitaan besarbesaran yang belum tentu kebenarannya. Bahaya bagi wartawan sendiri yaitu dapat dituduh melakukan Penghinaan/ pencemaran secara materiil yang sampai saat ini, aparat penegak hukum biasanya menggunakan Pasal 310 ayat (2) KUHP sebagai delik pers. Padahal, Pasal 310 ayat (2) KUHP bukan merupakan delik pers. Keistimewaan pasal ini berdasarkan adanya keistimewaan cara penyebarannya, namun bukan berarti bahwa semata-mata wartawan dapat diproses pidana menggunakan pasal ini. Oleh karena itu penegakan hukum terhadap kasus penghinaan/pencemaran, 
dapat dilakukan mediasi penal dengan

Model victim-offender mediation,
Model informal mediation dan Model community panel of courts.

\section{DAFTAR PUSTAKA}

\section{Buku}

Adji, Oemar Seno. Perkembangan Delik Pers di Indonesia. Jakarta: Erlangga, 1990.

Arief, Barda Nawawi. Bunga Rampai Kebijakan Hukum Pidana. Jakarta: Kencana Prenada Media Group, 2011. Atmasasmita, Romli. Sistem Peradilan Pidana Kontemporer. Jakarta: Kencana, 2011. Chazawi, Adami dkk. Tindak Pidana Pers (Penyerangan Terhadap Kepentingan Hukum. Bandung: Mandar Maju, 2015. Djatmika, Prija. Mediasi Penal Untuk Penyelesaian Perkara Penghinaan

Oleh Pers. Malang: Selaras, 2014.

Fuady, Munir dan Sylvia Laura L. Fuady.

Hak Asasi Tersangka Pidana. Jakarta:

Prenada Media Grup, 2015.

Hamzah, Andi. Asas-asas Hukum Pidana. Jakarta: Rineka Cipta, 1994.

Kusumaningrat, Hikmat dan Purnama Kusumaningrat. Jurnalistik, Teori dan Praktek. Bandung: Rosda Karya, 2005. Oetama, Jacob. Perspektif Pers Indonesia. Jakarta: LP3ES, 1987.

Sobur, Alex. Etika Pers (Profesionalisme Dengan Hati Nurani). Bandung: Humaniora Utama Press, 2001.

Susanto, Edy. dkk. Hukum Pers di Indonesia. Jakarta: Rineka Cipta, 2010.
Usman, Rachmadi. Mediasi Di Pengadilan (Dalam Teori dan Praktik). Jakarta: Sinar Grafika, 2012.

\section{Jurnal}

Huda, Chairul. "Makna Asas Praduga Tidak Bersalah dan Pemakaiannya dalam Praktek Pers". Jurnal Dewan Pers Edisi No 2, (November 2010): 89.

Loqman, Loebby. “Asas Praduga Tak Bersalah di dalam Pemberitaan oleh Media Massa. Jurnal Dewan Pers Edisi No 2, (November 2010): 60.

\section{Makalah}

Lumbuun, T. Gayus. Alternatif Dispute Resolution di dalam Sistem Peradilan Pidana. Jakarta: Makalah Workshop, 2007.

\section{Peraturan Perundang-undangan}

Undang-Undang Republik Indonesia No. 40 tahun 1999 tentang Pers.

Kitab Undang-Undang Hukum Acara Pidana.

\section{Naskah Internet}

Basmalah, Nurul. "Melacak Masa Lalu Jessica Terdakwa Kopi Sianida di Australia”. http://global.liputan6. 
com/read/2573847/melacak-masa- Qodar, Nafiysul. "Tanpa Otto Hasibuan

lalu-jessica-terdakwa-kopi-sianida-diaustralia?siteName=liputan6. Diakses 17 Desember 2016.

LIPUTAN ENAM PLUS. "Menurut Saksi Ahli Pembunuh Mirna Pintar". https:// www.vidio.com/watch/412607-enamplus-menurut-saksi-ahli-pembunuhmirna-pintar. Diakses 17 Desember 2016.
Pengacara Jessica Jadi Bahan Tertawaan". http://news.liputan6.com/ $\mathrm{read} / 2608126 /$ tanpa-otto-hasibuanpengacara-jessica-jadi-tertawaan. Diakses 27 Januari 2017. . "Jessica: Keluarga Saya Dipojokkan dan Menderita, Saya Bingung..." http://news.liputan6. com/read/2624337/jessica-keluargasaya-dipojokkan-dan-menderita-sayabingung. Diakses 7 April 2017. 